\title{
Creutzfeldt-Jakob Disease Transmitted by Dura mater Graft
}

\section{Dr. Manuel Clavel, C/ Margenat 19, E-08193 Bellaterra (Barcelona) (Spain)}

We report a 41-year-old woman who underwent a craniotomy and removal of a left clinoidal meningioma invading the cavernous sinus in May 1989. A graft of cadaveric dura mater (lyodura) was used as plastia, covering part of the left temporal lobe. A small tumoral fragment remaining was treated with radiotherapy

She stayed asymptomatic until October 1992 (41 months after surgery) when she began a rapidly progressive clinical deterioration (ataxia, dysarthria, pyramidalism, myoclonus and generalized slowing on the EEG). Two months later, a brain tissue frontal biopsy (fig. 1) led to the diagnosis of spongiform encephalopathy, thus suggesting Creutzfeldt-Jakob disease (CJD). The patient went into a progressive coma dying in February 1993.

The first description of a transmissible, person-to-person form of CJD was reported in 1974 in a patient who had received a corneal transplant [1]. Thadani et al. [2] published the first report of CJD transmitted by a cadaveric dura mater graft in 1988. Since then, 14 more cases [3-5] including ours have been reported (table 1). All of them, except 1, related to a commercial dura mater (Lyodura) made by Brown Melsungen Company of Germany.
CJD can be transmitted through particles containing an abnormal form of a prion protein. These infectious particles are highly resistant to most of the common sterilization procedures. The Committee on Health CJD can be transmitted through particles containing an abnormal form of a prion protein. These infectious particles are highly resistant to most of the common sterilization procedures. The Committee on Health
Care Issues of the American Neurological Association [6] recommended 1-hour exposure to 1 molar NaOH, or steam autoclaving for $1 \mathrm{~h}$ at $1322^{\circ} \mathrm{C}$ as the standard sterilization procedures for CJD tissue or contaminated material. After May 1987, according

Fig. 1. Spongiform change, neuron loss, and astrocytosis in the brain biopsy. HE. x 160 
w* " "\%/:;;";

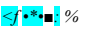

m1 $>$

*

$\%$

I 


\section{|**v|jiw}

*»

ft: 
Table 1. Dura mater graft cases

Age onset

Sex Latency

Original surgery

Initial symptoms

Thadani et al, 1988 [2] $]^{\mathrm{a}}$ Nisbetetal,, 1989 Masullo et al., 1989 Miyashita et al., 1991 Willison et al., 1991 Pocchieri et al,, $1992^{\mathrm{b}}$ Esmonde, 1993 Esmonde, 1993 Martinez-Lage et al., 1993 [4] Martinez-Lage et al, 1993 [4] Martinez-Lage et al,, 1993 [4] Martinez-Lage et al, 1993 [4] Laneetal., 1994 Yamadaetal., 1994 [5] Present case, 1995

\begin{tabular}{|c|c|c|c|c|}
\hline 28 & $\mathrm{~F}$ & 19 months & temporal cholesteatoma & unsteady gait, slurred speech \\
\hline 25 & $\mathrm{M}$ & 31 months & head injury & dementia \\
\hline 27 & $\mathrm{M}$ & 44 months & fibrose dysplasia & confusion, gait disturbance \\
\hline 26 & $\mathrm{~F}$ & 33 months & cerebellar hemangioblastoma & unsteady gait \\
\hline 32 & $\mathrm{~F}$ & 47 months & syringomyelia & dementia \\
\hline 32 & $\mathrm{~F}$ & 10 years & ethmoidal meningocele & ataxia \\
\hline 51 & $\mathrm{~F}$ & 84 months & syringomyelia & mood change \\
\hline 44 & $\mathrm{~F}$ & 96 months & meningioma & visual symptoms \\
\hline 19 & $\mathrm{M}$ & 16 months & cerebellar astrocytoma & ataxia \\
\hline 57 & $\mathrm{~F}$ & 43 months & syringomyelia & ataxia \\
\hline 18 & $\mathrm{M}$ & 79 months & cerebellar astrocytoma & ataxia \\
\hline 34 & $\mathrm{M}$ & 105 months & syringomyelia & dizziness and slurred speech \\
\hline 28 & $\mathrm{~F}$ & 60 months & Arnold-Chiari & cerebellar dysfunction \\
\hline 31 & $\mathrm{~F}$ & 56 months & pituitary adenoma & slurred speech, unsteady gait \\
\hline 41 & $\mathrm{~F}$ & 42 months & meningioma & instability \\
\hline
\end{tabular}

Cadaver lyodura was used in all cases. ${ }^{\bar{a}}$ Lyodura lot No. 2105 used. ${ }^{5}$ Noncommercial lyodura used.

to Braun Melsungen AG, their procedures of collection and processing of dura mater were revised in order to reduce the risk of CJD transmission, including the manufacturing process of exposure for $1 \mathrm{~h}$ to 1 molar $\mathrm{NaOH}$. However, some authors $[7,8]$ have emphasized that complete inactivation of the agent producing CJD cannot be obtained, and that such treatment merely prolongs the incubation period.

The epidemic proportion of this group of patients with CJD transmitted by dura mater graft could be larger if we think of the potential transmission of the disease to patients with severe head injuries and malignant brain tumors who, due to the short period of survival after surgery, do not surpass the theoretical incubation period of CJD. These groups of patients are the major working load of any neurosurgical department.

Brown et al. [9] have shown in a recent work that allelic homozygosity at polymorphic codon 129 was present in $92 \%$ of the patients with CJD studied. This supports the thesis that the genotype of codon 129 enhances the susceptibility to CJD iatrogenic infections.

We agree with others [10] that despite the assurance on the safety of the product treated with 1 molar $\mathrm{NaOH}$, this homograft source should be abandoned, and we advocate preferential use of temporalis fascia, fascia lata, pericranium or synthetic substitutes.

References

1 Duffy P, Wolf J, Collins G, DeVoe AG, Streeten B, Cowen D: Possible person-to-person transmission of Creutzfelld-Jakob disease. N Engl J Med 1974;290:692-693.

2 Thadani V, Penar PL, Partington J, Kalb R, Janssen R, Schonberger LB, Rabkin CS, Prichard JW: Creutzfeldt-Jakob disease probably acquired from a cadaveric dura mater graft. J Neurosurg 1988;69:766-769.

3 Centers for Disease Control: Creutzfeldt-Jakob disease in patients who received a cadaveric dura mater graft: Spain, 1985-1992. MMWR 1993; 42:560-564.

4 Martinez-Lage JF, Sola J, Poza M, Esteban JA: Pediatric Creutzfeldt-Jakob disease: Probable transmission by a dural graft. Child's Nerv Syst 1993;9: 239-242.
5 Yamada S, Aiba T, Endo Y, Hara M, Kitamoto T, Tateishi J: Creutzfeldt-Jakob disease transmitted by a cadaveric dura mater graft. Neurosurgery 1994;34:740-744.

6 Committee on Health Care Issues, American Neurological Association: Precautions in handling tissues, fluids, and other contaminated materials from patients with documented or suspected Creutzfeld-Jakob

7 disease. Ann Neurol 1986;19:75-77.
Tamai Y, Taguchi F, Miura S: Inactivation of the Creutzfeldt-Jakob disease agent. Ann Neurol 1988;24:466-467.

8 Tateishi J, Tashima T, Kitamoto T: Inactivation of the Creutzfeldt-Jakob disease agent (letter). Ann Neurol 1988;24:466.

9 Brown P, Cervenakova L, Goldfarb LG, McCombie WR, Rubenstein R, Will RG, Pocchiari M, Martinez-Lage JF, Scalici C, Masullo C, Graupera G, Ligan J, Gajdusek DC: Iatrogenic Creutzfeldt-Jakob

disease: An example of the interplay between ancient genes and modern medicine. Neurology 1994:44:291-293.

10 Horwitz NH: Comment to the paper of Lane KL, Brown P, Howell DN, Crain BJ, Hulette CM, Burger PC, DeArmond SJ: Creutzfeldt-Jakob disease in a pregnant woman with an implanted dura mater graft.

Neurosurgery 1994;34:739-740. 